\title{
Seasonal Changes of Chlorophyll $a$ and Environmental Characteristics in the Sea of Oman
}

\author{
Al-Hashmi, Khalid A. Claereboudt*, Michel R. Al-Azri, Adnan, R. Piontovski, Sergey. A. \\ Sultan Qaboos University, Department Marine Science and Fisheries College Agricultural and Marine Sciences, Box 34 \\ Al-Khod 123 Sultanate of Oman
}

\begin{abstract}
Monthly estimates of chlorophyll $a$, temperature, salinity, and nutrients were collected through sampling at two stations from January 2001 to January 2002, in and near Bandar Al-Khyran, the largest semi-enclosed bay on the southern coast of the Sea of Oman. Although the sampling location was at the limit of the tropical range, the seasonal changes of the coastal phytoplankton were more related to temperate dynamics, showing seasonal fluctuation of more than $10^{\circ} \mathrm{C}$. Sharp temperature drops observed in August and July were likely due to rises of the thermocline under the influence of coastal upwelling events or to deep water injections along the north coast of Oman generated by changes in the coastal wind patterns. Overall, small phytoplanktonic cells $[0.7-5 \mu \mathrm{m}]$ dominated the phytoplankton community of the mixed layer with an average of $69.7 \%$ and $73.5 \%$ of the extracted chlorophyll $a$ at the station "Inside" and "Outside" the bay, respectively.
\end{abstract}

Keywords: Arabian Sea, picoplankton, chlorophyll $a$, coastal upwelling, phytoplankton blooms.

\section{INTRODUCTION}

The Sultanate of Oman occupies the Northeastern corner of the Arabian Peninsula bordering three marine regions: the Sea of Oman, the Arabian Sea, and the Arabo-Persian Gulf (Fig. 1). Apart from the outflow of the Arabo-Persian Gulf waters and a wind-driven circulation of the mixed layer, a prominent dynamic feature of the Sea of Oman is the mesoscale variability. Cyclonic and anticyclonic eddies affect the upwelling and downwelling of nutrient rich sub-surface waters [1-3]. These eddies are most active during the Southwest (SW) monsoon $[4,5]$ in particular in the northwestern part of the Arabian Sea put some persists all year long in the Sea of Oman.

In terms of seasonal changes, the monsoonal regime makes the Omani coast a valuable study case for monitoring the coastal ecosystem affected by one of the most intensive coastal upwelling in the Worlds Ocean.

Despite several international expeditions carried out in the northwestern Arabian Sea in the frame of the JGOFS project and some studies along the Arabian Sea coast [6], the ecology of the coastal waters of Oman, particularly along the Sea of Oman, is still poorly understood. For example, the JGOFS cruises sampled less than two months each, down the Arabian Sea coast only [6-8].

We present here the results of the first one-year long study of the seasonal changes of chlorophyll $a$ in three size

*Address correspondence to this author at Sultan Qaboos University, Department Marine Science and Fisheries College Agricultural and Marine Sciences, Box 34 Al-Khod 123 Sultanate of Oman; Tel: (968) 24141249 / (968) 2414 1246; Fax: (968) 244 13418;

E-mail:michelc@squ.edu.om,mclaereboudt@mac.com fractions, accompanied by CTD casts and nutrient sampling., in the coastal Sea of Oman.

\section{MATERIALS AND METHODS}

Monthly sampling was carried out in the Bay of Bandar Al-Khyran (Fig. 1), which is the largest semi-enclosed bay on the southern coast of the Sea of Oman with an approximate surface area of $4 \mathrm{~km}^{2}$ and an average depth of $10 \mathrm{~m}$. The bay has only 3 inlets and is surrounded by steep rocky hills and cliffs of Permian limestones and shales lined with shallow coral communities. A permanent temperature records was obtained from Fahl Island at $8 \mathrm{~m}$ in depth, less than $20 \mathrm{~km}$ northwest of the Bay.

Two stations were sampled: station "Out", outside the bay in the open water (Fig. 1) representing the conditions occurring outside of the direct influence of the embayment (bottom depth $=40 \mathrm{~m}$ ), and station "In", inside the bay (bottom depth $=14 \mathrm{~m}$ ). Between 22 January and 26 December 2001 samples were collected monthly at both stations except in April, May and July during which two samples were collected. Sampling took place at high tide to limit the variability associated with tidal mixing.

Temperature, conductivity and depth were measured with an Idronaut-Ocean Seven 316 CTD probe fitted with an additional sensor for chlorophyll (Fluorescence). Surface values for temperature and in-situ fluorescence were averaged over the depth of the mixed layer (maximum gradient in temperature) for comparison with chlorophyll $a$ concentrations obtained from discrete water samples. Sub-surface water samples representative of the mixed layer were collected at $2 \mathrm{~m}$ in depth with Niskin bottles for the analyses of nitrates, nitrites, total inorganic phosphorus and silica. Samples 


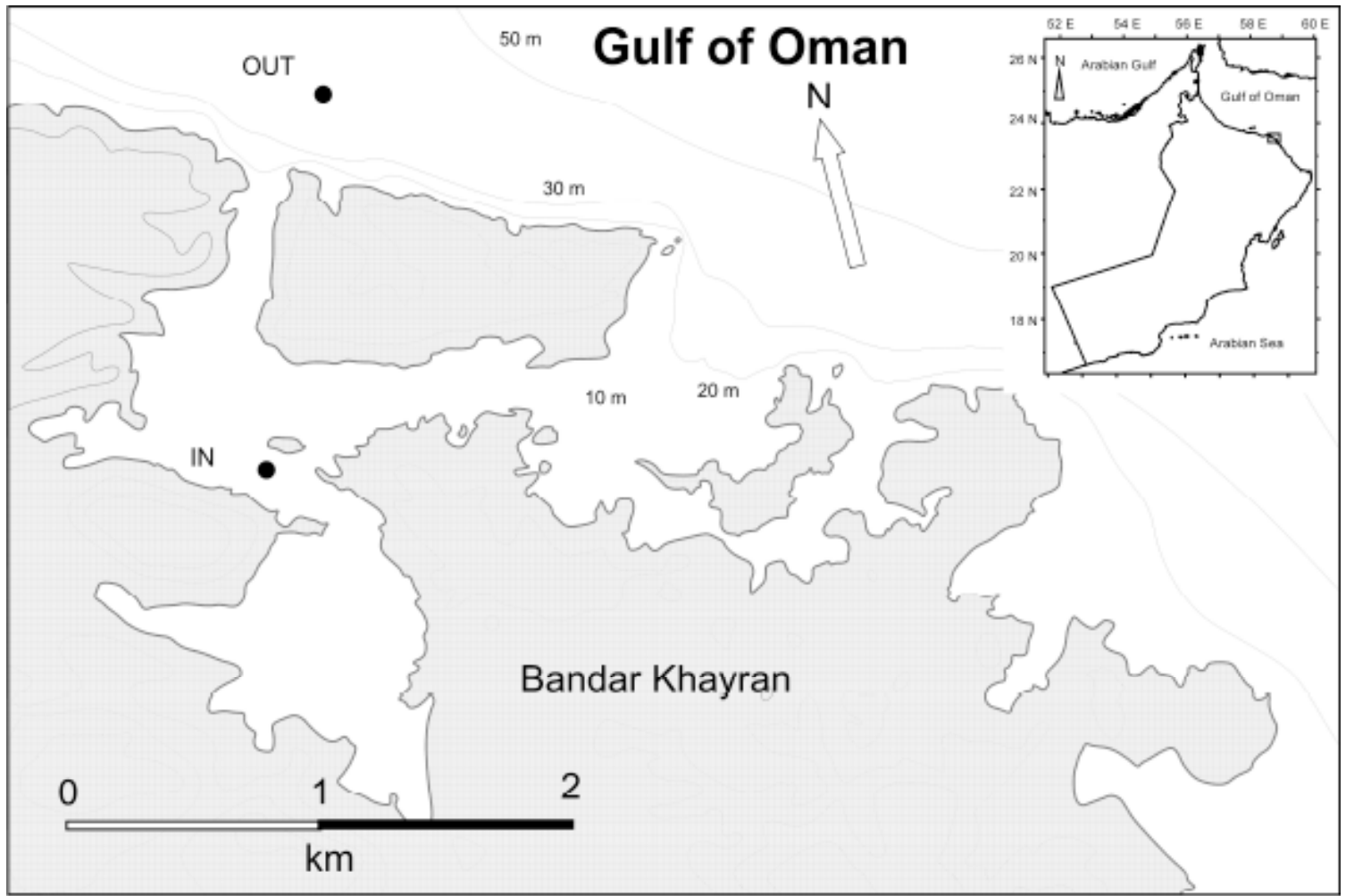

Fig. (1). Map of the coast of Oman (a) and sampling sites.

of water were immediately frozen for storage. Water sampled were later thawed and analyzed for nutrients using a 5channels SKALAR FlowAccess auto-analyzer according to the procedures described in Strickland and Parsons [9] and modified according to the recommendation of the manufacturer (Skalar analytical, 1996).

For cell size distributions three additional 2-liter samples from each station were collected and immediately filtered through 3 sets of filters: [1] Whatman GF/F glass fiber filter with $0.7 \mu \mathrm{m}$ pore size, [2] nytex nylon filters with $5 \mu \mathrm{m}$ mesh size and [3] nitex filters with $20 \mu \mathrm{m}$ mesh size. Filters were kept frozen in the dark until analysis.

In the laboratory filters were placed into a $90 \%$ acetone solution and left overnight at $4^{\circ} \mathrm{C}$ in the dark for pigments extraction. Filters were ground at the beginning of the extraction process to facilitated extraction, and then centrifuged just before analyses in a Turner Design Model 10-AU fluorometer. Chlorophyll $a$ concentrations in each size class (0.7-5 $\mu \mathrm{m}, 5-20 \mu \mathrm{m}$ and $>20 \mu \mathrm{m})$ were calculated by difference between the concentration values measured on the three filters. All fluorescence values were corrected for phaeophytin using acidification [9].

\section{RESULTS}

Continuous temperature records at Fahal Island, about $20 \mathrm{~km} \mathrm{NW}$ of Bandar Al-Khyran showed a progressive increase from February $\left(23^{\circ} \mathrm{C}\right)$ to June $\left(30^{\circ} \mathrm{C}\right)$ then an alternation of high and low values between July and October

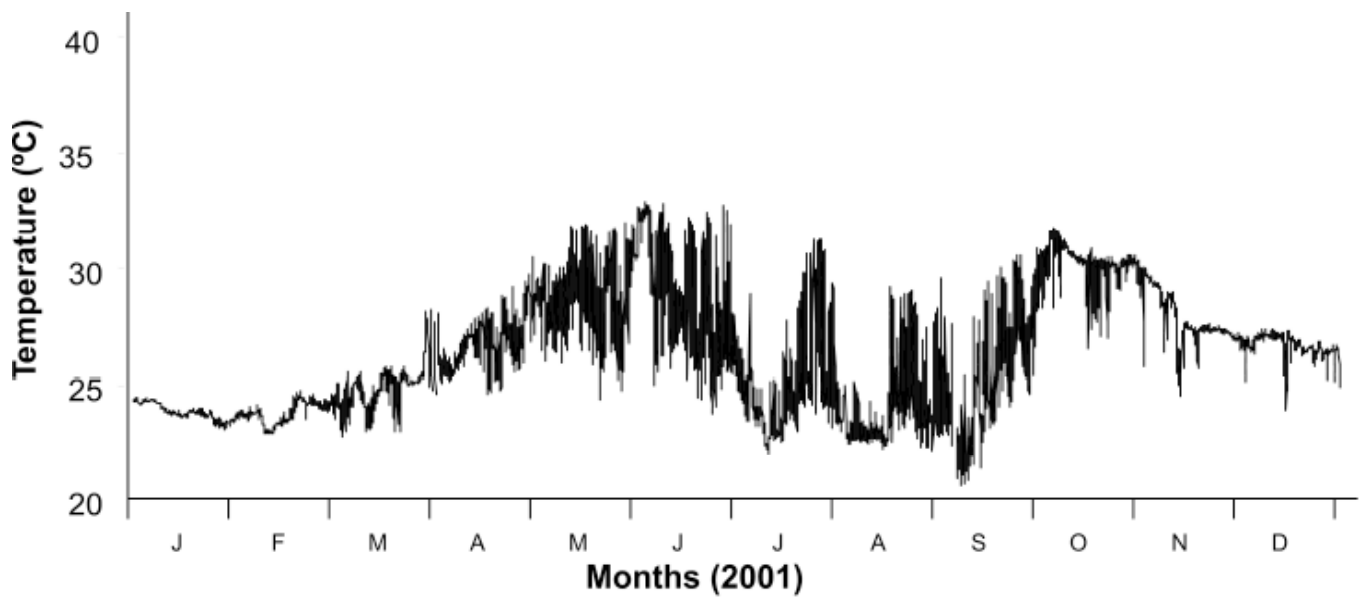

Fig. (2). Continuous temperature records at $8 \mathrm{~m}$ in depth obtained from station near Fahal Island. 

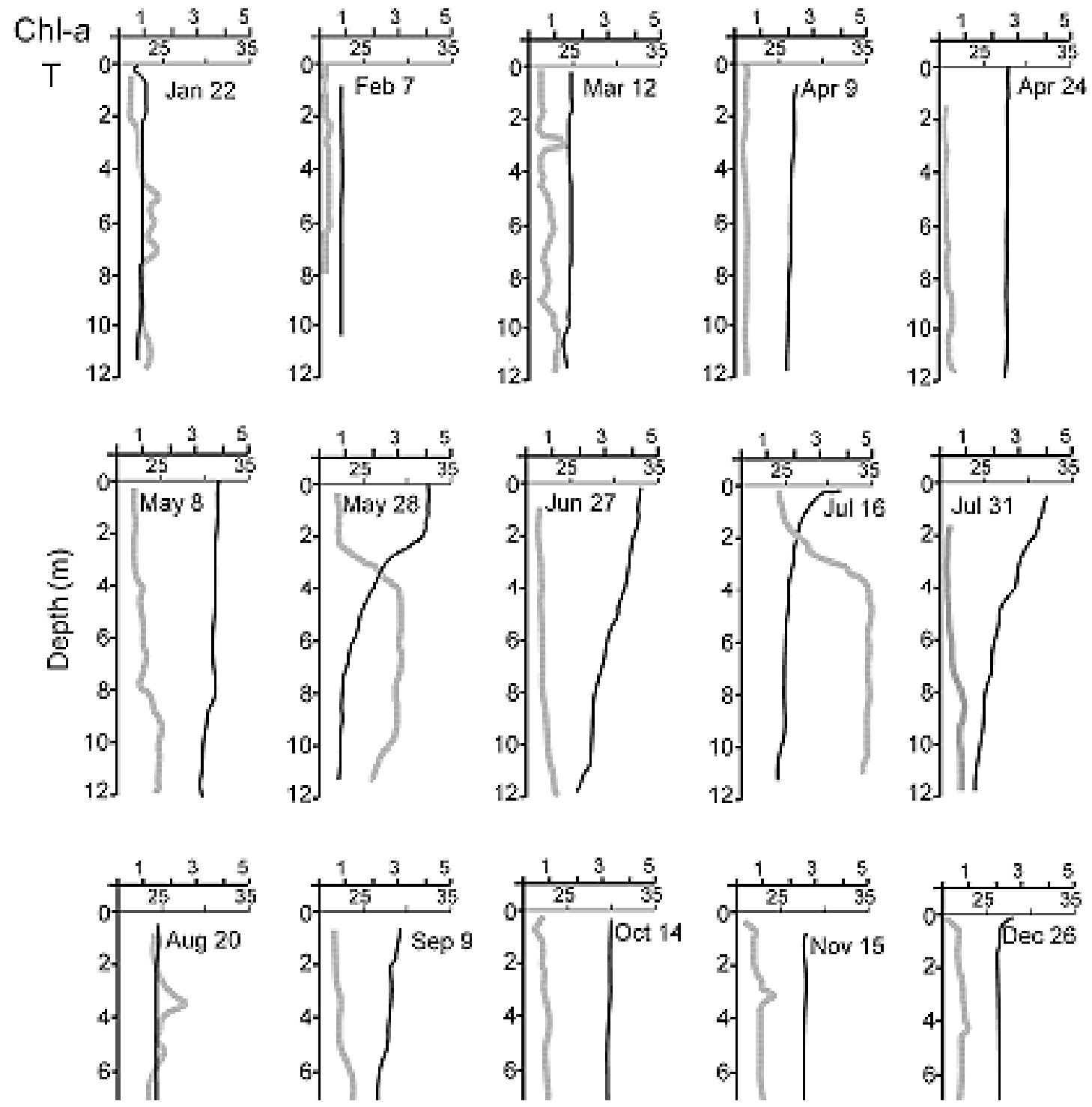

Fig. (3). Seasonal fluctuations in temperature $\left({ }^{\circ} \mathrm{C}\right)$ and chlorophyll $a\left(\mu \mathrm{g} 1^{-1}\right)$ at station "Inside: In" in Bandar Al-Khyran Bay.

(Fig. 2). Between November and January, the surface temperature progressively decreased. From 22 January to 8 May the water of both stations was homogenously distributed. From 28 may to 31 July, a progressive temperature stratification developed with a thermocline set around 2 meters in depth at station "In" and around 7 meters at station "Out". During this period, temperatures ranged between $32^{\circ} \mathrm{C}$ at the surface and $22^{\circ} \mathrm{C}$ at the bottom for both stations.

At station "In" the thermocline progressively deepened and then reached the bottom on 27 June leading to a nearly homogenous water column at $27^{\circ} \mathrm{C}$ (Fig. 3). In contrast at station "Out" the thermocline persisted during the summer at different depths from 5 meter in 8 May to more than $15 \mathrm{~m}$ towards October and November (Fig. 2).

Nitrate concentrations, exhibited a maximum on 7 February for both stations "In" and "Out" with $2.3 \mu \mathrm{M}$ and $2.7 \mu \mathrm{M}$ respectively (Fig. 4). Concentrations then decreased at both stations to values comprised between $0.4 \mu \mathrm{M}$ and $0.6 \mu \mathrm{M}$. Two small peaks $(1.0 \mu \mathrm{M}$ and $1.5 \mu \mathrm{M})$ were observed at Station "In" on 31 July and 14 October. Nitrite concentra- tions showed little variation throughout the sampling period with concentrations ranging between $0.1-0.4 \mu \mathrm{M}$ (Fig. 5) and a single peak observed in January and February at both stations with values around $1.0 \mu \mathrm{M}$. Phosphate concentrations at station "Out" fluctuated markedly between 0.5 and $3.5 \mu \mathrm{M}$ with a strong peak observed in April-May. Phosphate at station "In" was relatively homogenous throughout the sampling period with concentrations varying between $0.4 \mu \mathrm{M}$ and $1.5 \mu \mathrm{M}$ (Fig. 4). Silicate showed low values $(0.5-1.0 \mu \mathrm{M})$ between March and July and considerably higher values $(1-2 \mu \mathrm{M})$ between August and January (Fig. 5).

The two stations showed similar values in nutrient concentrations for nitrite, nitrate and silicate (paired t-tests, p > 0.25). Phosphate concentration inside the bay ("In" station) were significantly lower than outside the embayment (paired t-test, $\mathrm{n}=15, \mathrm{t}=2.31, \mathrm{p}<0.05$ ).

Chlorophyll $a$ showed a distinct seasonal variation at both stations. In the mixed layer at station "Out" chlorophyll a concentration remained below $0.4 \mathrm{mg} \cdot \mathrm{m}^{-3}$ from January 

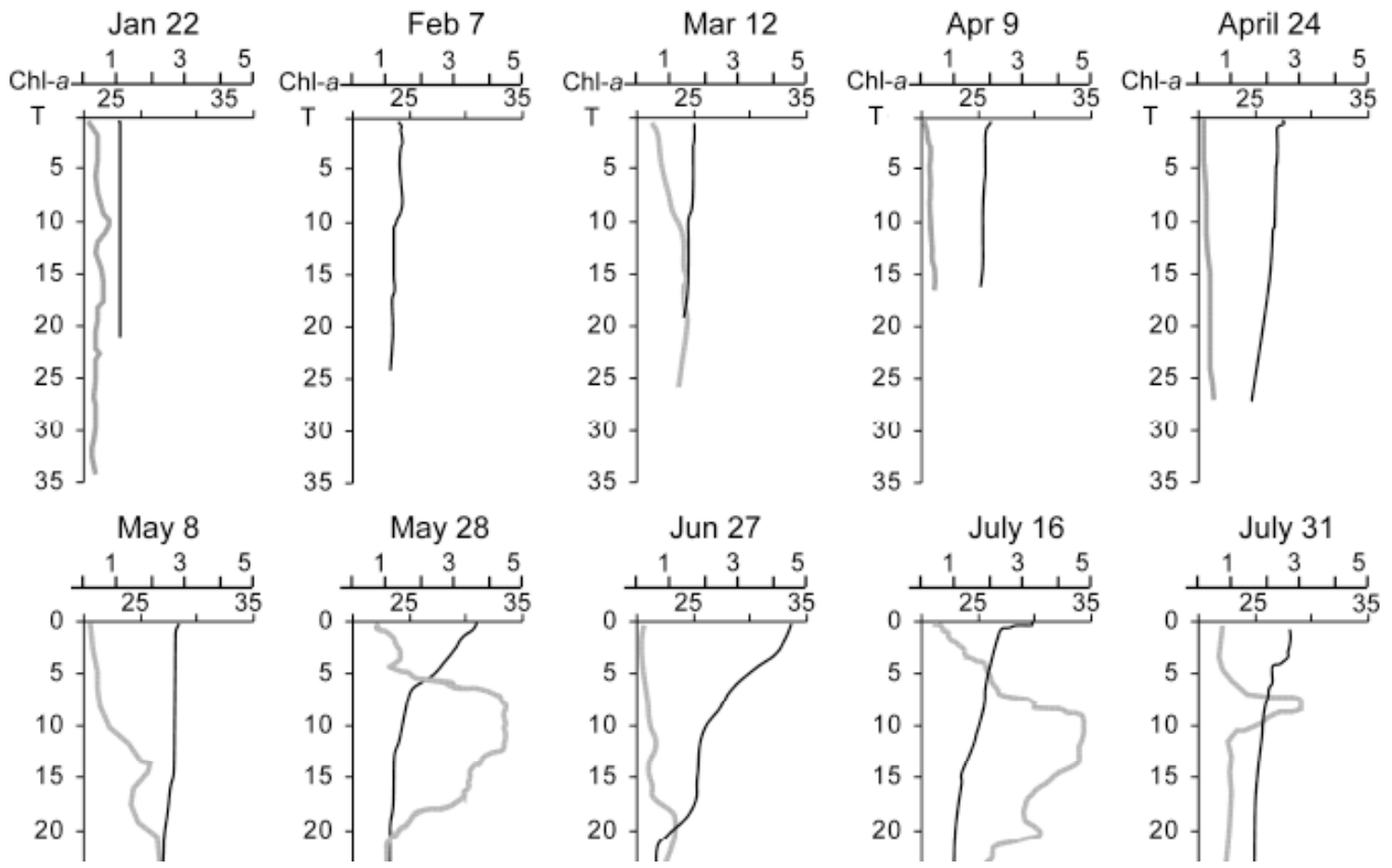

Fig. (4). Seasonal fluctuations in temperature $\left({ }^{\circ} \mathrm{C}\right)$ and chlorophyll a ( $\left.\mu \mathrm{g} 1-1\right)$ at station "Outside: Out" in Bandar Al-Khyran Bay.

until May (Fig. 6). At station "In" during the same period, values varied between 0.2 and $0.7 \mathrm{mg} \cdot \mathrm{m}^{-3}$. In May, chlorophyll $a$ in the mixed layer increased to values between 1 and $2.5 \mathrm{mg} \cdot \mathrm{m}^{-3}$. Maximum surface chlorophyll $a$ was attained on 16 July both inside and outside the embayment with 2.7 and $1 \mathrm{mg} \cdot \mathrm{m}^{-3}$ respectively.

At both stations, from January to May, chlorophyll $a$ was distributed almost evenly in the water column from the surface to the maximum sampled depth $(40 \mathrm{~m}$ and $15 \mathrm{~m}$ respectively; Fig. 6). From May until September, a distinct chlorophyll $a$ subsurface maximum was observed between 5 and $20 \mathrm{~m}$ at station "Out" and between 4 and $7 \mathrm{~m}$ at station "In". The maximum chlorophyll concentration was in excess of 5 $\mathrm{mg} \cdot \mathrm{m}^{-3}$ on 16 July 2001 at both stations (Fig. 6). After the subsurface maximum observed during the summer, chlorophyll $a$ concentrations decreased to values around $1 \mathrm{mg} \cdot \mathrm{m}^{-3}$ distributed almost equally in the water column from October to December.

Overall, small phytoplanktonic cells $(0.7-5 \mu \mathrm{m})$ dominated the mixed layer phytoplankton community with on average $69.7 \%$ and $73.5 \%$ of the extracted chlorophyll $a$ at the "In" and "Out" station respectively (Table $\mathbf{1}$ ).

At the "Out" station, in two samples (12 March and 26 December), the relative proportion of small cells $(0.7-5 \mu \mathrm{m})$ dropped below $50 \%$ and the proportion of net plankton $(>20 \mu \mathrm{m})$ increased to $>40 \%$ (Table 1). At the "In" station, samples exhibited the same trend. The contribution of the 5$20 \mu \mathrm{m}$ size class was often lower at the "Out" station than at the "In" station but the difference was non significant (paired t-test, $\mathrm{p}=0.12$ ). At this station, the 5-20 $\mu \mathrm{m}$ size class contribution fluctuated during the season with generally larger values (20-30\%) observed in the spring (12 March-8 May), occasional peaks in the fall (20 August and 14 October; 25-
$30 \%$ ) and low values (3-15\%) observed during the summer (Table 1).

\section{DISCUSSION}

\section{Temperature, Stratification and Nutrients}

The temperature regime of the coastal waters in northern Oman follows a distinct annual cycle with low temperature observed in the winter and highest sea surface temperatures observed in the summer (Fig. 7). The two sharp temperature drops observed in August and July are likely due to rises of the thermocline under the influence of coastal upwelling events or to deep water injections along the north coast of Oman generated by the coastal wind patterns and mesoscale cyclonic eddies. Such dramatic changes in temperature have been reported in the region $[10,11]$ and are thought to trigger major shifts in the dynamics of coastal ecosystems [10].

The small peaks in nutrients concentrations (nitrates, phosphates and to a lesser extend nitrites) observed in the surface water during summer and early fall (July-October) corresponded likely to temporary injections of nutrients across the thermocline during these coastal upwelling events. The amplitude of the variation in nutrients, however, remained small. This could be due to a rapid uptake of nutrient by a fast growing phytoplanktonic community, a limited input through the strong thermocline or to the coarse resolution of our sampling protocol. The high resolution temperature data at $8 \mathrm{~m}$, near Fahl Island shows the frequency and duration of these events (Fig. 2).

The values of nitrate-nitrite concentrations were similar in our study to that observed in other coastal coral communities (around $1 \mu \mathrm{M})[12,13]$ and were similar inside and outside the embayment. The few reported values for nitrate- 

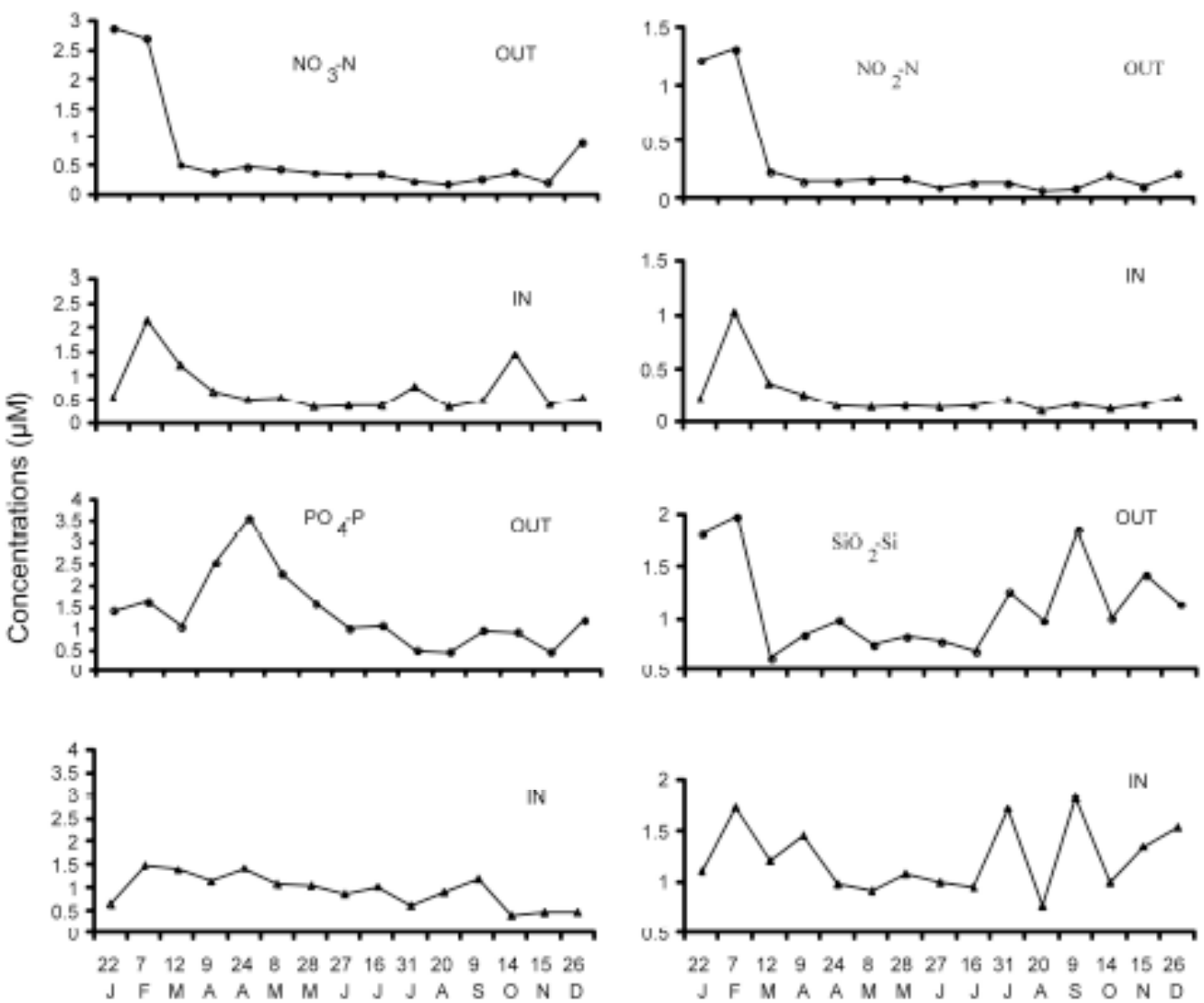

Months-2001

Fig. (5). Seasonal fluctuations in surface nutrients $(\mu \mathrm{M})$ at station "Inside" and "Outside" in Bandar Al-Khyran Bay.

nitrite in the Sea of Oman waters were slightly lower than that of this study with concentrations between 0.223 [14] and $0.398[15]$.

The observed values of phosphate on the other hand were considerably higher in this study (around $1 \mu \mathrm{M}$ ) than that reported for other tropical areas $0.13-0.34 \mu \mathrm{M}$; $[13,16]$ and higher outside than inside, particularly between March and May. Similar conditions of relative enrichment in phosphorus in the surface layer were reported elsewhere in the Sea of Oman (Quriyat) and described as an indication of potentially nitrogen limited environments for primary producers [14]. The relative impoverishment of the embayment in terms of phosphate might be due to its adsorption to the carbonate rich (coral reef and sedimentary rock) sediments lining the shallow bay [17].

\section{Chlorophyll a and Phytoplankton}

The chlorophyll $a$ concentrations in the surface water corresponded to published values for oligotrophic surface tropical waters $(0.2-1.5 \mu \mathrm{gl}-1$; [18]). The higher values (1.2$1.5 \mathrm{gl}^{-1}$ ) observed in May-September (the summer in the Sea of Oman) corresponded to a period of thermocline vertical movement under the influence of local wind driven upwelling events and probable injection of nutrients through mixing across the thermocline. The intense stratification measured during this summer period generated a subsurface chlorophyll $a$ maximum which reached often values above $3.0 \mu \mathrm{gl}^{-1}$. Such subsurface maxima are commonly associated with strong stratification [19].
The higher chlorophyll $a$ concentrations observed inside the bay $\left(1.5 \mu \mathrm{gl}^{-1}\right)$ in comparison to the concentrations measured outside $\left(0.8 \mu \mathrm{gl}^{-1}\right)$ might result from a continuous low level nutrient enrichment by coral exudates favoring growth of picoplankton [20]. About $30 \%$ of the shores of Bandar Al-Khyran are indeed lined with a good cover coral community [21]. Alternatively, grazing by zooplankton might also be enhanced in the outer station by a more turbulent surface layer [22] or by a depleted zooplankton community inside the bay due to coral predation [23].

The low chlorophyll $a$ values observed during the winter despite higher nutrients episodes resulted probably from light limitations due to the lack of stratification and hence a deep mixed layer. Estimates of the light penetration using PAR measurements indicated that the 1\% surface irradiance was between $25-30 \mathrm{~m}$ in depth in the winter at this location [24] without any significant density stratification.

\section{Size Fractions}

Detailed assessments of the size structure of phytoplankton communities have received much attention due to the potential influence of cell size on the fate of primary production [25]. A striking characteristic of the surface phytoplankton community at Bandar Al-Khyran is the dominance of the smallest cell size class $(0.7-5 \mu \mathrm{m})$ throughout most the samplings period (Table 1). Because of their larger halfsaturation uptake constant, phytoplankton communities in nutrient enriched waters, such as recently upwelled water, often show a large proportions of larger phytoplankton cells 


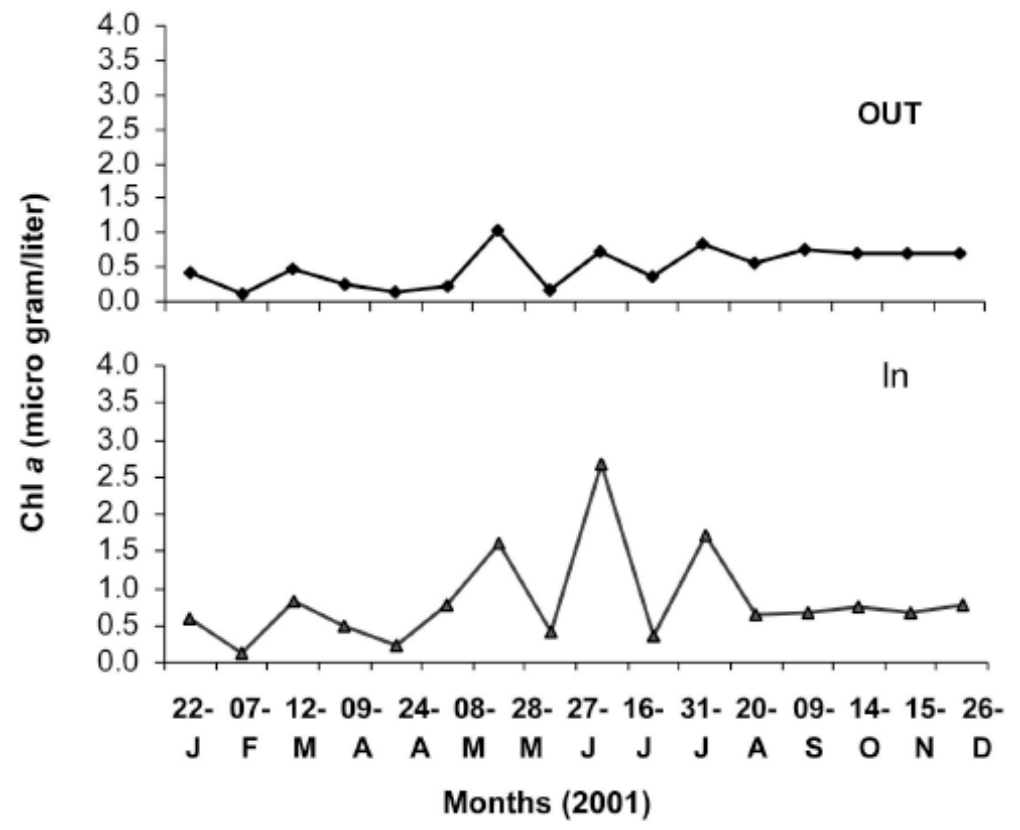

Fig. (6). Seasonal fluctuations of surface Chlorophyll $a\left(\mu \mathrm{gl}^{-1}\right)$ in Bandar Al-Khyran Bay.

Table 1. Percentage of Extracted Chlorophyll $a$ in Three Size Fractions $(<5 \mu \mathrm{m}, 5-20 \mu \mathrm{m}$ and $>20 \mu \mathrm{m})$ at Both Stations In and Out at All Sampling Dates

\begin{tabular}{|c|c|c|c|c|c|c|}
\hline \multirow[t]{2}{*}{ Date } & \multicolumn{3}{|c|}{ Station "Out" } & \multicolumn{3}{|c|}{ Station "In" } \\
\hline & $<5 \mu \mathrm{m}$ & $5-20 \mu \mathrm{m}$ & $>20 \mu \mathrm{m}$ & $<5 \mu \mathrm{m}$ & $5-20 \mu \mathrm{m}$ & $>20 \sim \mathrm{m}$ \\
\hline 07-Feb & 69.1 & 16.7 & 14.2 & 89.7 & 6.0 & 4.3 \\
\hline 12-Mar & 49.3 & 2.5 & 48.3 & 57.2 & 22.0 & 20.9 \\
\hline 24-Apr & 70.1 & 2.0 & 27.9 & 65.5 & 23.3 & 11.1 \\
\hline 08-May & 77.8 & 3.6 & 18.7 & 34.7 & 26.6 & 38.7 \\
\hline 28-May & 71.8 & 0.5 & 27.7 & 80.5 & 12.7 & 6.8 \\
\hline 31-Jul & 66.4 & 23.8 & 9.7 & 75.4 & 3.5 & 21.1 \\
\hline 20-Aug & 71.7 & 21.0 & 7.3 & 58.2 & 29.9 & 11.9 \\
\hline 09-Sep & 94.4 & 2.0 & 3.7 & 85.0 & 7.1 & 7.9 \\
\hline 14-Oct & 77.9 & 3.2 & 18.9 & 60.4 & 24.4 & 15.1 \\
\hline $15-\mathrm{Nov}$ & 85.5 & 10.7 & 3.8 & 85.8 & 6.0 & 8.3 \\
\hline 26-Dec & 37.1 & 18.3 & 44.7 & 91.9 & 2.8 & 5.3 \\
\hline
\end{tabular}

(net phytoplankton) [25-27] and low nutrient surface tropical waters are often dominated by picoplankton [28, 29]. This has been quantified by a power relationship with a negative exponent (-0.25) linking maximum nutrient uptake rate to cell size [30]. The nitrate-nitrite levels in our mixed layer remained almost always below the threshold usually docu- mented for the dominance of large cells $(\mathrm{NO} 2+\mathrm{NO} 3>1 \mu \mathrm{M}$ [31]).

Similar throughout dominance by small cells has been reported for coral dominated atoll lagoons [20, 32], shelf waters of the Great Barrier Reef [33] and in the coral reef 


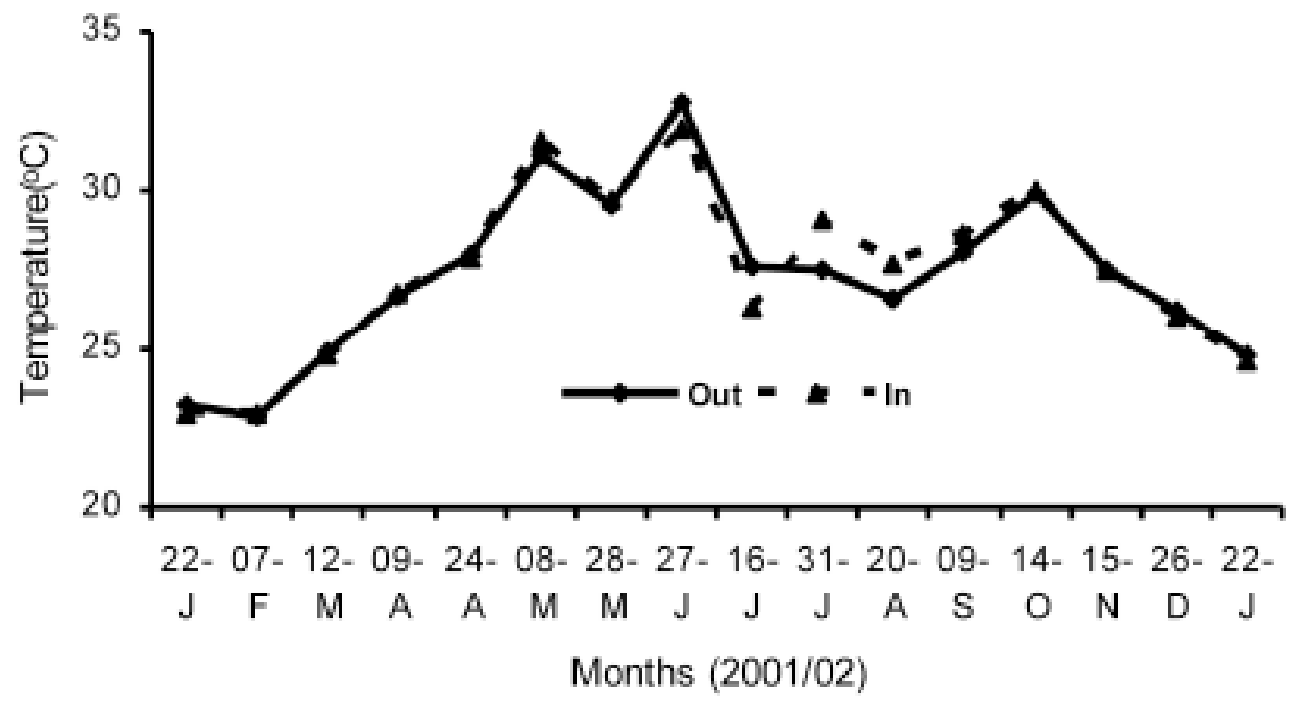

Fig. (7). Seasonal fluctuations of sea surface temperature $\left({ }^{\circ} \mathrm{C}\right)$ in Bandar Al-Khyran Bay.

waters off Sesoko Island in Japan [13]. Such picoplanktonic dominance is also characteristic of the inter-monsoon periods of the Arabian Sea [34-36] and of many tropical and subtropical waters where picoplankton typically represent more than $70 \%$ of total chlorophyll $a$ [16]. In this study the only periods when nano- or net plankton contributed for more than $40 \%$ of the total chlorophyll $a$ corresponded to the winter period (with measured nitrate + nitrite $>1 \mu \mathrm{M}$ ) or to the period of rapid temperature decrease in summer and fall, likely due to upwelling and at least transient injections of nutrients in the upper water column through mixing across a shoaling thermocline. During these short term events, sufficient nutrients are injected in the upper water column, to favor some growth in the $>5 \mu \mathrm{m}$ phytoplanktonic cell fraction [37].

Generally, most of the variability in chlorophyll $a$ is associated with changes in the abundance of the large size fractions, implying that picophytoplankton remains relatively constant $[38,39]$. In our samples, the variability came mostly from small size cells $(0.7-5 \mu \mathrm{m})$ indicating that in some cases, it is the small fraction of phytoplankton that drives changes in abundances and productivity [37, 40].

\section{CONCLUSIONS}

In the Bay of Bandar Al-Khyran, seasonal temperature fluctuations (of up to $8^{\circ} \mathrm{C}$ over short periods of time in summer) suggest a very dynamic upper water column influenced by coastal upwelling generated by changes in wind patterns. The intense summer stratification has generated a subsurface chlorophyll $a$ maximum with values above 3.0 $\mu \mathrm{gl}^{-1}$.

Smallest size phytoplankon $(0.7-5 \mu \mathrm{m})$ dominated the mixed layer phytoplankton community throughout the year, with an average $70 \%$ and $74 \%$ of the extracted chlorophyll $a$, inside and outside the bay, respectively.

In the future, higher frequency sampling (weekly or even daily) should be applied to resolve the short-term dynamics of upwelling: nutrient availability, phytoplankton and zooplankton interaction, from May through October.

\section{ACKNOWLEDGEMENTS}

Thanks to the Department of Marine Science and Fisheries at Sultan Qaboos University for supporting this research. Special thanks to Harib Al-Habsi for running the nutrient analyses and CTD deployments. We wish to extend our appreciations to the Research Vessels crew and staff in the Department of Marine Science and Fisheries: Saleh AlMashary, Manolito Barte, Khamis Al-Riyami, Salim AlKhusaibi, Aiysha Ambu Ali, and Mohammed Al-Gheithi.

\section{REFERENCES}

[1] Banse K, Piontkovski SA, Eds. The mesoscale structure of the epipelagic ecosystem of the open northern Arabian Sea. Hyderabad, India: Universities Press 2006.

[2] Mann K, Lazier J. Dynamics of marine ecosystems: biologicalphysical interactions in the oceans. Blackwell Publishing; 2006.

[3] Thangaraja M. Hydro-biology of Oman. Muscat- Oman: MSFC research, Ministry of Agriculture and Fisheries 1995; Report No.: 95-1.

[4] Madhupratap M, Gopalakrishnan TC, Haridas P, et al. Lack of seasonal and geographic variation in mesozooplankton biomass in the Arabian Sea and its structure in the mixed layer. Curr Sci 1996; 71(11): 863-8.

[5] Swallow J. Some aspects of the physical oceanography of the Indian Ocean. Deep-Sea Res 1984; 31: 639-50.

[6] Savidge G, Lennon J, Matthews AJ. A shore-based survey of upwelling along the coast of Dhofar region, southern Oman. Continental Shelf Res 1990; 10(3): 259-75.

[7] Shalapyonok A, Olson R, Shalapyonok L. Arabian Sea phytoplankton during Southwest and Northeast Monsoons 1995: composition, size structure and biomass from individual cell properties measured by flow cytometry. Deep-Sea Res Part II 2001; 48(6-7): 1231-61.

[8] Stuart V, Sathyendranath S, Platt T, Maass H, Irwin B. Pigments and species composition of natural phytoplankton populations: effect on the absorption spectra. J Plank Res1998; 20(2): 187-217.

[9] Strickland J, Parsons T. A practical handbook of seawater analysis. Ottawa Fishries Research Borad: Canada 1972.

[10] Claereboudt M, Hermosa G, McLean E, Eds. Plausible cause of massive fish kill in the Gulf of Oman. In: Proceeding of the first international conference on Fisheries, Aquaculture and 
Environments in the Northwest Indian Ocean: Sultan Qaboos University, Oman 2001.

[11] Coles SL, Seapy DG. Ultra-violet absorbing compounds and tumorous growths on acroporid corals from Bandar Khayran, Gulf of Oman, Indian Ocean. Coral Reefs 1998; 17: 195-8.

[12] Crossland CJ. Dissolved nutrients in coral reef waters. In: Barnes DJ, Eds. Perspectives in Coral Reefs. South Africa: AIMS 1993; pp. 56-68.

[13] Tada K, Sakai K, Nakano Y, Takemura A, Montani S. Sizefractionated phytoplankton biomass in coral reef waters off Sesoko Island, Okinawa, Japan. J Plankton Res Oxford Univ Press 2003; 125: 991-7.

[14] Stirn J, Al-Habsi H, Hunt R, Siddeek M, Villanueva J. Initial stages of upwelling in the Arabian Sea and concomitant phytoplankton blooms, and euphotic layer hypoxia. Final Report of the Scientific Workshop on Results of the R/V Mt. Mitchell Cruise in the ROPME Sea Area. Kuwait: ROPME1993. Report No. 2.

[15] Dorgham M, Moftah A. Environmental conditions and phytoplankton distribution in the Arabian Gulf and Gulf of Oman, September 1986. J Mar Biol Assoc 1989; 31(1-2): 36-53.

[16] Gin K, Zhang S, Lee Y. Phytoplankton community structure in Singapore's coastal waters using HPLC pigment analysis and flow cytometry. J Plankton Res Oxford Univ Press 2003; 25: 1507-19.

[17] Smith S, Atkinson M. Phosphorus limitation of net production in a confined aquatic ecosystem. Nature 1984; 307(5952): 626-7.

[18] Tarran G, Burkill P, Edwards E, Woodward E. Phytoplankton community structure in the Arabian Sea during and after the SW monsoon, 1994. Deep-Sea Res Part II 1999; 46(3-4): 655-76.

[19] Barlow RG, Mantoura RFC, Cummings DG. Monsoonal influence on the distribution of phytoplankton pigments in the Arabian Sea. Deep Sea Res [II] 1999; 46: 677-99.

[20] Ferrier-Pages C, Furla P. Pico- and nanoplankton production in the two largest atolls of French Polynesia. Mar Ecol Prog Ser 2001; 211: 63-76.

[21] Claereboudt MR. Reef corals and coral reefs of the Gulf of Oman. Muscat: Historical Association of Oman - Al-Roya 2006.

[22] Saiz E, Alcaraz M, Paffenhöfer G. Effects of small-scale turbulence on feeding rate and gross-growth efficiency of three Acartia species [Copepoda: Calanoida]. J Plankton Res 1992; 14(8): 1085-97.

[23] Holzman R, Reidenbach MA, Monismith SG, Koseff JR, Genin A. Near-bottom depletion of zooplankton over a coral reef II: relationships with zooplankton swimming ability. Coral Reefs 2005; 24: 87-94.

[24] Al-Hashmi KA. Biomass, phytoplankton composition and species dynamics in Bandar Khayran Bay, Gulf of Oman (MSc thesis). AlKhod: Sultan Qaboos University 2004.

[25] Legendre L, Le Fevre J. From individual plankton cells to pelagic marine ecosystems and to global biogeochemical cycles: Particle analysis in oceanography. New York: Springer 1991; pp. 261-300.
[26] Morales C, Blanco J, Braun M, Reyes H, Silva N. Chlorophyll-a distribution and associated oceanographic conditions in the upwelling region off northern Chile during the winter and spring 1993. Deep-Sea Res Part I 1996; 43(3): 267-89.

[27] Webber D, Roff J. Influence of Kensington harbor on the phytoplankton community of the near shore Hillshire coast, southeast Jamaica. Bull Mar Sci 1996; 59(2): 245-58.

[28] Campbell L, Vaulot D. Photosynthetic picoplankton community structure in the subtropical North Pacific Ocean near Hawaii [station ALOHA]. Deep Sea Res [I] 1993; 40: 2043-60.

[29] Raven J. Physiological consequences of extremely small size for autotrophic organisms in the sea. Can Bull Fish Aquat Sci 1986; 214: 1-70.

[30] Moloney CL, Field JG. General allometric equations for rates of nutrient uptake, ingestion and respiration in plankton organisms. Limnol Oceanogr 1989; 34(7): 1290-9.

[31] Agawin NSR, duarte CM, Agustí S. Nutrient and temperature control of the contribution of picoplankon to phytoplankton biomass and production. Limnol Oceanogr 2000; 45(3): 591-600.

[32] Charpy L. Phytoplankton biomass and production in two Tuamotu atoll lagoons [French Polynesia]. Mar Ecol Prog Ser 1996; 145(13): $133-42$.

[33] Furnas M, Mitchell A. Phytoplankton dynamics in the central great barrier reef-II: primary production. Continental Shelf Res 1987; 7 : 1049-62.

[34] Burkill P, Leakey R, Owens N, Mantoura R. Synechococcus and its importance to the microbial food web of the northwest Indian Ocean. Deep Sea Res [II] 1993; 40: 773-82.

[35] Jochem F. Phototrophic picoplankton community structure in three different pelagic regimes in the Arabian Sea. Mar Ecol Prog Ser Oldendorf 1995; 117(1): 307-14

[36] Savidge G, Gilpin L. Seasonal influences on size-fractionated chlorophyll a concentrations and primary production in the NorthWest Indian Ocean. Deep-Sea Rese Part II 1999; 46(3-4): 701-23.

[37] Marañon E, Holligan P, Barciela R, et al. Patterns of phytoplankton size structure and productivity in contrasting open-ocean environments. Mar Ecol Prog Ser 2001; 216: 43-56.

[38] Raimbault P, Rodier P, Taupier-Letage I. Size fraction of phytoplankton in the Ligurian Sea and the Algerian Basin[Mediterranean Sea]: size distribution versus total concentration. Mar Microbial Food Webs 1988; 3(1): 1-7.

[39] Rodriguez J, Blanco J, Jimenez-Gomez F, et al. Patterns in the size structure of the phytoplankton community in the deep fluorescence maximum of the Alboran Sea[southwestern Mediterranean]. DeepSea Res [Part I]: Oceanogr Res Pap 1998; 45(10): 1577-93.

[40] Brown SL, Landry MR, Barber RT, et al Picoplankton dynamics and production in the Arabian Sea during the 1995 Southwest monsoon. Deep-Sea Res II 1999; 46: 1745-68.

(C) Alessio Guarino; Licensee Bentham Open

This is an open access article licensed under the terms of the Creative Commons Attribution Non-Commercial License (http://creativecommons.org/licenses/ by-nc/3.0/) which permits unrestricted, non-commercial use, distribution and reproduction in any medium, provided the work is properly cited. 